\title{
KETERAMPILAN AKTIF RESEPTIF DAN PEMAHAMAN KAIDAH BAHASA INDONESIA PARA GURU SD SEKOTA PONTIANAK
}

\section{ACTIVE RESEPTIVE SKILLS AND COMPREHENSION OF INDONESIAN GRAMMAR OF ELEMENTARY SCHOOL TEACHERS IN PONTIANAK}

\author{
Irmayani \\ Balai Bahasa Kalimantan Barat \\ irmayanipnk@gmail.com
}

\begin{abstract}
ABSTRAK
Tulisan ini bertujuan mendeskripsikan kemahiran berbahasa Indonesia para guru SD di Kota Pontianak berdasarkan komponen linguistik yang terdapat di dalam tes bahasa. Kemampuan tersebut diketahui melalui hasil tes UKBI Seri Pelatihan yang dilakukan oleh para guru SD pada tahun 2018. Metode deskriptif digunakan untuk memaparkan hasil analisis data. Berdasarkan hasil pembahasan, diperoleh bahwa kemahiran berbahasa Indonesia para guru SD di Pontianak berada di level Sangat Unggul, Unggul, Madya, Semenjana dan Marjinal. Mayoritas kemampuan para guru tersebut berada pada level Madya,sedangkan minoritasnya berada di level Marjinal. Selain itu, didapati pula bahwa nilai tertinggi para guru SD di Kota Pontianak adalah bidang Memahami Bacaan. Sebaliknya, untuk para guru yang berada dilevel Sangat Unggul, bidang Merespons Kaidah adalah bidang yang diperoleh dengan nilai paling tinggi. Sementara itu, berbanding terbalik dengan komponen linguistik yang diperoleh para guru berdasarkan nilai tertinggi, mayoritas guru SD di Kota Pontianak lebih menguasai bidang Memahami Bacaan. Hal ini terlihat dari intensitas kemunculan nilai tinggi untuk bidang tersebut pada tiap peringkat.
\end{abstract}

Kata Kunci: UKBI, keterampilan reseptif, kaidah bahasa, guru SD

\begin{abstract}
This paper aims to describe the language skills of Indonesian language mastered by the elementary school teachers in Pontianak based on the linguistic component in the language test. The skill level was based on the result of UKBI Training Series conducted for elementary school teachers in 2018. The descriptive method is used to present the results of data analysis. Based on the results of the discussion, it was found that the Indonesian language skill of the elementary school teachers in Pontianak was at the level of Very Advanced, Advanced, Upper Intermediate, Intermediate and Elementary. The majority of these teachers were at the Upper Intermediate level, while the minority was at the Elementary level. In addition, it was also found that the elementary school teachers in Pontianak City got the highest score in the section of Understanding the Reading. In contrast, teachers who were graded Very Advanced got the highest score on the section of Responding the Grammar. However, in contrast to the highest score on the linguistic component, most elementary school teachers in Pontianak got the highest score in the section of Understanding the Reading. This can be seen from the frequency of high scores for that section at every rank.

Keywords: UKBI, receptive skills, grammar, elementary school teachers, city of Pontianak
\end{abstract}




\section{PENDAHULUAN}

Komunikasi sangat diperlukan oleh manusia sebagai makhluk sosial untuk mempertahankan kebutuhan bersosialisasi mereka. Alat untuk mewujudkannya adalah bahasa, dalam hal ini bahasa verbal. Artinya, dengan berbahasa, manusia dapat memenuhi kebutuhan mereka untuk berkehidupan sosial dengan lebih baik.

Untuk mewujudkan hal tersebut diperlukanlah keterampilan berbahasa. Guion mendefinisikan keterampilan sebagai bagian dari kompetensi. Seperti dikutip oleh Spencer and Signe M. Spencer, secara lebih jelas Guion mendeskripsikan keterampilan sebagai kemampuan untuk melakukan tugas-tugas yang berkaitan dengan fisik dan mental (Pramesti, 2015: 85).

Dalam praktik berbahasa, keterampilan tadi terbagi ke dalam empat komponen, yaitu mendengarkan, berbicara, membaca, dan menulis. Berdasarkan sifatnya, empat keterampilan tersebut dikelompokkan menjadi dua kategori, yaitu reseptif dan produktif. Keterampilan berbahasa produktif adalah aspek keterampilan berbahasa yang bersifat mengeluarkan atau memroduksi bahasa. Sebaliknya, aspek reseptif adalah keterampilan berbahasa yang bersifat menerima atau menyerap bahasa (Mulyati \& Cahyani, 2015: 1.4). Jika berbicara dan menulis menjadi bagian dari komponen bahasa yang bersifat produktif, mendengarkan dan membaca adalah komponen keterampilan berbahasa yang bersifat reseptif. Walaupun termasuk dalam kategori yang sama, mendengarkan dan membaca memiliki perbedaan media. Media keterampilan mendengarkan adalah bunyi bahasa, sedangkan keterampilan membaca adalah tulisan.

Seperti telah dijelaskan sebelumnya, untuk dapat bersosialisasi secara verbal dengan lebih baik, manusia harus memiliki empat keterampilan berbahasa. Orang yang memiliki keterampilan berbahasa secara optimal, setiap tujuan komunikasinya akan tercapai (Mulyati, 2005: 1.3). Wahyuni (2013: 220) juga menjelaskan bahwa kemampuan mengungkapkan pikiran secara lisan memerlukan penguasaan bahasa yang baik agar mudah dimengerti oleh orang lain dan membutuhkan pembawaan yang tepat. Penguasaan bahasa yang baik tidak hanya berlaku pada pengungkapan pikiran secara lisan saja. Pengungkapan pikiran secara tulis dan kemampuan berbahasa secara reseptif juga memerlukan penguasaan tersebut secara baikpula.

Proses komunikasi akan berjalan dengan baik jika tujuan komunikasi tercapai dengan penguasaan kerterampilan berbahasa yang optimal. Hal ini disebabkan oleh setiap orang dapat menyampaikan dan menerima pesan dengan baik pula. Jika ini terjadi, kehidupan sosial para pengguna bahasa tersebut akan menjadi lebih baik karena tercapainya tujuan komunikasi tadi dan prosesnya berjalan dengan lancar. Ada seperangkat tes yang dapat dijadikan sebagai instrumen untuk mengukur tingkat penguasaan bahasa tersebut. Seperangkat tes bahasa yang dimaksud adalah Uji Kemahiran Berbahasa Indonesia atau disingkat dengan UKBI.

Secara lisan, UKBI mengukur keterampilan aktif reseptif peserta uji dalam kegiatan mendengarkan dan mengukur keterampilan aktif produktif peserta uji dalam kegiatan berbicara. Dalam pengunaan bahasa tulis, UKBI mengukur keterampilan aktif reseptif peserta uji dalam kegiatan membaca dan mengukur keterampilan aktif produktif peserta uji dalam kegiatan menulis (Ibrahim dkk., 
Tuah Talino

Tahun XIV Volume 14 Nomor 2 Edisi 4 Desember 2020

ISSN 0216-079X E-ISSN 2685-3043

Balai Bahasa Kalimantan Barat

2016: 19). Komponen bahasa yang diujikan di dalam UKBI tidak hanya empat keterampilan berbahasa, tetapi juga pemahaman seseorang tentang kaidah bahasa Indonesia. Konsep UKBI merupakan kemampuan menggunakan bahasa Indonesia yang baik dan benar dalam berbagai ranah kehidupan yang dapat terukur melalui wacana lisan dan tulis serta kaidah bahasa Indonesia. Yang terukur melalui kaidah bahasa Indonesia adalah kepekaan terhadap penggunaannya (Zalmansyah, 2016: 220).

UKBI bertujuan memberikan penilaian standar pengguna bahasa Indonesia dalam berbahasa Indonesia tanpa mempertimbangkan kapan, di mana, dan bagaimana kemampuan itu diperoleh (Zalmansyah, 2016: 221). Itu artinya siapa saja dapat memanfaatkan UKBI untuk mengetahui tingkat kemahirannya dalam memahami serta menggunakan bahasa Indonesia tanpa terkecuali, termasuk guru, dalam hal ini guru SD.

Berbicara tentang UKBI dalam kaitannya dengan dunia pendidikan dan pengajaran, kompetensi guru dalam memahami serta menggunakan bahasa Indonesia sangatlah penting. Sebagai ujung tombak pendidikan dasar, guru memegang peranan yang sangat penting bagi keberhasilan pendidikan di negeri ini (Zalmansyah, 2016: 225). Selain itu, seperti diikutip oleh Mulyanto Sumardi, Badudu berpendapat bahwa minimnya kemampuan berbahasa Indonesia di kalangan kaum terpelajar ini juga disebabkan oleh kualitas guru (dalam Syahrir, 2014: 148). Oleh karena itu, sudah semestinya para guru memahami dan menguasai seluk beluk bahasa Indonesia agar kerapian dan ketepatan praktik berbahasa dalam segala bidang dan tujuan tercapai dengan baik (Budhiono, 2017: 18).

Untuk itu, penulis merasa perlu untuk mengetahui kompetensi berbahasa Indonesia para guru SD di Kota Pontianak melalui UKBI. Kompetensi tersebut berkaitan dengan predikat kemahiran mereka dalam berbahasa Indonesia melalui UKBI. Selain itu penulis juga mendeskripsikan nilai tertinggi dari komponen kebahasaan yang diperoleh para guru pada setiap peringkatnya. Tidak hanya itu, penulis juga mendeskripsikan komponen kebahasaan yang paling dominan dikuasai oleh para guru tersebut. Dengan kata lain, penulis mengkaji tingkat kemahiran mereka di bidang bahasa dan diperinci kembali dengan mengkaji komponen kebahasaan yang paling dikuasai berdasarkan nilai tertinggi pada setiap peringkat yang diperoleh. Tidak hanya sampai di situ, penulis juga mengkaji komponen kebahasaan yang paling dipahami oleh setiap peuji dari 600 orang guru tadi. Kajian ketiga ini dilihat dari sering munculnya nilai-nilai terbaik para guru secara perseorangan.

Kajian yang berkaitan dengan UKBI ini telah pernah dilakukan. Beberapa di antaranya adalah Maryanto (2010) dengan judul "Tes Uji Kemahiran Berbahasa Indonesia (UKBI) sebagai Arena Riset Linguistik", Achril Zalmansyah (2013) dengan judul "Uji Kemahiran berbahasa Indonesia (UKBI) bagi Guru dan Siswa Sekolah Menengah Pertama Se-Lampung Utara”, Elvina Syahrir (2014) dengan judul "Kemampuan Guru Bahasa Indonesia dalam Menyelesaikan Soal UKBI di Pekanbaru", dan R. Hery Budhiono (2017) dengan judul "Kompetensi Berbahasa Indonesia Guru Sekolah Dasar di Kalimantan Tengah. Kajian-kajian tersebut memiliki pumpunan yang berbeda antara satu dan lainnya. 
Tuah Talino

Tahun XIV Volume 14 Nomor 2 Edisi 4 Desember 2020

ISSN 0216-079X E-ISSN 2685-3043

Balai Bahasa Kalimantan Barat

Maryanto (2010), melalui tulisannya, meninjau tes UKBI dan dampaknya terhadap pengajaran bahasa di sekolah ataupun dampaknya bagi pembaruan teori bahasa. Menurutnya, perubahan paradigma, baik dalam teori bahasa maupun pengajaran bahasa, dimungkinkan karena kehadiran tes bahasa. Pada derajat tertentu, tes UKBI telah mempengaruhi perubahan kebijakan pendidikan dalam pengajaran bahasa Indonesia. Tes UKBI juga mengandung dimensi sosial dan politik karena dapat berfungsi sebagai alat seleksi dalam pendidikan dan pengajaran di Indonesia.

Di samping itu, dalam kaitannya dalam pembaruan teori, tes bahasa dipandang sebagai arena untuk membuktikan kepercayaan tentang bahasa sebagai sebuah konstruk multidimensional yang dapat dipilah menjadi berbagai komponen. Dalam perkembangannya, tes bahasa belum menyediakan kerangka teoretis bagaimana komponen-komponen itu secara khusus berinteraksi untuk menentukan kemahiran berbahasa. Namun demikian, kecenderungan yang akan datang menujukkan paradigma teori bahasa berupa konstruk kemahiran bahasa yang diharapkan dapat berubah menjadi lebih utuh.

Selanjutnya, Zalmansyah (2013) mengkaji kemahiran berbahasa para guru dan siswa SMP di Kabupaten Lampung Utara. Dengan metode analisis deskriptif kualitatif dan kuantitatif sederhana, Zalmansyah menemukan bahwa hasil UKBI para guru dan siswa SMP se-Kabupaten Lampung Tengah pada tahun 2013 dapat dikatakan cukup baik. Artinya, sebagian besar peserta berada pada peringkat Madya dan Semenjana dengan perolehan angka rata-rata 300-400. Menurut Zalmansyah, hal ini disebabkan oleh peserta masih mengalami kendala dalam berkomunikasi untuk keperluan keprofesian yang kompleks dan masih mengalami kendala yang besar jika berkomunikasi untuk keperluan keilmuan.

Dengan dilatarbelakangi oleh rendahnya kemampuan UN Bahasa Indonesia di Pekanbaru, Syahrir (2014) mengkaji kemampuan guru bahasa Indonesia dalam menyelesaikan soal UKBI di Pekanbaru. Syahrir menetapkan para guru bahasa Indonesia, baik SMA, SMP, maupun SD, sebagai sumber data karena menurutnya tinggi rendahnya kemampuan siswa sangat berkorelasi dengan kemampuan para guru bahasa Indonesia. dari penganalisisan data diperoleh temuan bahwa nilai rerata UKBI guru SMA memperoleh skor paling tinggi, nilai rerata UKBI guru SMP memperoleh skor sedang, sedangkan nilai rerata UKBI guru SD memperoleh skor paling rendah.

Sementara itu, di Kalimantan Tengah, Budhiono (2017) mengkaji kompetensi berbahasa Indonesia Guru Sekolah Dasar.Sampel daerah yang diambil adalah Palangka Raya, Kuala Kapuas, Kasongan, pangkalan Bun, dan Muara Teweh. Kelima daerah tersebut merupakan ibukota Provinsi dan kabupaten. Dengan mengambil sampel sebanyak 185 orang guru SD, Budhiono menemukan bahwa daerah yang memiliki rata-rata skor UKBI tertinggi adalah Kuala Kapuas. Sebaliknya, Palangka Raya sebagai pusat pemerintahan sekaligus ibukota Kalimantan Tengahmalah berada di urutan terbawah.

Sebagai parameter untuk menguji kemahiran berbahasa Indonesia seseorang, hasil UKBI dipetakan ke dalam 7 peringkat, predikat, dan rentang skor. Ketujuh predikat dapat diserangkaikan dalam satu ungkapan Isu Unggul 
Tahun XIV Volume 14 Nomor 2 Edisi 4 Desember 2020

ISSN 0216-079X E-ISSN 2685-3043

Balai Bahasa Kalimantan Barat

Manangitas, Istimewa, Sangat Unggul, Unggul, Madya, Semenjana, Marjinal, dan Terbatas. Peringkat dan Predikat UKBI tersebut dideskripsikan sebagai berikut.

\begin{tabular}{|c|c|c|c|}
\hline Peringkat & Predikat & Skor & $\begin{array}{c}\text { Deskripsi Kemahiran } \\
\text { Berbahasa }\end{array}$ \\
\hline I & Istimewa & $725-800$ & Sempurna \\
\hline II & Sangat Unggul & $641-724$ & Sangat Tinggi \\
\hline III & Unggul & $578-640$ & Sangat Memadai \\
\hline IV & Madya & $482-577$ & Memadai \\
\hline V & Semenjana & $405-481$ & Cukup Memadai \\
\hline VI & Marjinal & $326-404$ & Tidak Memadai \\
\hline VII & Terbatas & $251-325$ & Sangat Tidak memadai \\
\hline
\end{tabular}

(Laman UKBI, Badan Bahasa)

Materi UKBI meliputi empat keterampilan berbahasa, yaitu keterampilan mendengarkan, membaca, menulis, dan berbicara. Selain itu, UKBI juga berisi materi tentang kaidah bahasa. Kelima materi tersebut diejawantahkan ke dalam lima seksi pengujian, yaitu Seksi I Mendengarkan, Seksi II Merespons Kaidah, Seksi III membaca, Seksi IV Menulis, dan Seksi V Berbicara (Ibrahim, dkk., 2016: 19).

Lima seksi tersebut menggunakan empat ranah yang berkaitan dengan kecakapan hidup sebagai tema soal tes. Empat ranah yang dimaksud adalah kesintasan yang berkaitan dengan keperluan personal, sosial yang berkaitan dengan perihal kemasyarakatan, vokasional yang berkaitan dengan masalah keprofesian, dan akademik yang berhubungan dengan hal-hal yang bersifat keilmiahan. Berikut ini adalah paparan tingkat kemahiran berbahasa dikaitkan dengan tema-tema tersebut.

\begin{tabular}{|c|c|c|c|c|c|}
\hline \multirow[b]{2}{*}{$\begin{array}{l}\mathbf{N} \\
\mathbf{O}\end{array}$} & \multirow[b]{2}{*}{$\begin{array}{c}\text { PREDIKA } \\
\text { T }\end{array}$} & \multicolumn{4}{|c|}{ TEMA SOAL TES } \\
\hline & & $\begin{array}{c}\text { I } \\
\text { KESINTA } \\
\text { SAN }\end{array}$ & $\begin{array}{c}\text { II } \\
\text { SOSIAL } \\
\text { (KEMASYARA } \\
\text { KATAN) }\end{array}$ & $\begin{array}{c}\text { III } \\
\text { KEPROFESIA } \\
\text { N }\end{array}$ & $\begin{array}{c}\text { IV } \\
\text { AKADEMIK } \\
\text { (KEILMIAHA } \\
\text { N) }\end{array}$ \\
\hline 1 & Istimewa & $\begin{array}{l}\text { tidak ada } \\
\text { kendala }\end{array}$ & tidak ada kendala & tidak ada kendala & $\begin{array}{c}\text { tidak ada } \\
\text { kendala }\end{array}$ \\
\hline 2 & $\begin{array}{l}\text { Sangat } \\
\text { Unggul }\end{array}$ & $\begin{array}{l}\text { tidak ada } \\
\text { kendala }\end{array}$ & tidak ada kendala & tidak ada kendala & $\begin{array}{c}\text { masih ada } \\
\text { kendala untuk } \\
\text { yang kompleks }\end{array}$ \\
\hline 3 & Unggul & $\begin{array}{c}\text { tidak ada } \\
\text { kendala }\end{array}$ & tidak ada kendala & tidak ada kendala & terkendala \\
\hline 4 & Madya & $\begin{array}{c}\text { tidak } \\
\text { terkendala }\end{array}$ & tidak terkendala & $\begin{array}{c}\text { masih terkendala } \\
\text { untuk yang } \\
\text { kompleks }\end{array}$ & terkendala \\
\hline 5 & Semenjana & $\begin{array}{c}\text { tidak } \\
\text { terkendala }\end{array}$ & $\begin{array}{l}\text { masih terkendala } \\
\text { untuk yang } \\
\text { kompleks }\end{array}$ & $\begin{array}{c}\text { masih terkendala } \\
\text { untuk yang } \\
\text { kompleks } \\
\end{array}$ & terkendala \\
\hline 6 & Marjinal & $\begin{array}{c}\text { tidak } \\
\text { terkendala }\end{array}$ & tidak terkendala & terkendala & terkendala \\
\hline 7 & Terbatas & $\begin{array}{l}\text { tidak } \\
\text { terkendala }\end{array}$ & terkendala & terkendala & terkendala \\
\hline
\end{tabular}

(Badan Bahasa) 
Tuah Talino

Tahun XIV Volume 14 Nomor 2 Edisi 4 Desember 2020

ISSN 0216-079X E-ISSN 2685-3043

Balai Bahasa Kalimantan Barat

Selain itu, soal untuk keterampilan mendengarkan dan membaca dipetakan ke dalam kisi-kisi berdasarkan dimensi kognitif dan dimensi pengetahuan dari beragam bidang ilmu pengetahuan. Soal juga akan berkaitan dengan teks yang dipilih sesuai dengan ranah komunikasi yang dirujuk di dalam dialog, monolog, dan bacaan (Ibrahim dkk, 2016: 19).

Selain menekankan pengukuran terhadap empat keterampilan mikrobahasa tersebut, UKBI juga mengukur pengetahuan peserta uji dalam penerapan kaidah bahasa Indonesia (ejaan, bentuk dan pilihan kata, serta kalimat) (Ibrahim dkk., 2016: 19-20).

Seksi I (mendengarkan) bertujuan mengukur kemampuan memahami informasi yang diungkapkan secara lisan. Wacana lisan tersebut berbentuk dialog dan monolog yang membahas berbagai topik dalam situasi dan kondisi yang beragam. Seksi II (merespons kaidah) bertujuan mengukur kepekaan peserta uji dalam merespons penggunaan kaidah bahasa Indonesia ragam formal. Kaidah tersebut meliputi ejaan, bentuk dan pilihan kata, dan kalimat. Seksi III (membaca) bertujuan untuk mengukur kemampuan peserta uji dalam memahami informasi yang disamapaikan dalam bentuk wacana tulis atau bacaan. Bacaan tersebut disajikan dalam berbagai laras bidang ilmu (Zalmansyah, 2016: 222 -224).

\section{METODE}

Tulisan ini menggunakan skor UKBI sebagai data. Skor tersebut diperoleh dari hasil nilai tes UKBI Seri Pelatihan para Guru se-Kota Pontianak selama 12 hari pada tahun 2018. Berikut ini adalah daftar waktu dan wilayah kecamatan yang terpilih.

\section{Tabel 1}

Pemilihan Jadwal dan wilayah Pengetesan UKBI

\begin{tabular}{|l|l|l|}
\hline NO & \multicolumn{1}{|c|}{ TANGGAL } & \multicolumn{1}{c|}{ TEMPAT PELAKSANAAN } \\
\hline 1. & 3 September 2018 & Kecamatan Pontianak Tenggara \\
\hline 2. & 5 September 2018 & Kecamatan Pontianak Selatan \\
\hline 3. & 7 September 2018 & Kecamatan Pontianak Selatan \\
\hline 4. & 12 September 2018 & Kecamatan Pontianak Kota \\
\hline 5. & 14 September 2018 & Kecamatan Pontiank Kota dan Pontianak Barat \\
\hline 6. & 18 September 2018 & Kecamatan Pontianak Barat \\
\hline 7. & 20 September 2018 & Kecamatan Pontianak Barat \\
\hline 8. & 24 September 2018 & Kecamatan Pontianak Timur \\
\hline 9. & 26 September 2018 & Kecamatan Pontianak Timur \\
\hline 10. & 28 September 2018 & Kecamatan Pontianank Timur dan Pontianak Utara \\
\hline 11. & 2 Oktober 2018 & Kecamatan Pontianak Utara \\
\hline 12. & 4 Oktober 2018 & Kecamatan Pontianak Utara \\
\hline
\end{tabular}

Penentuan wilayah dan sekolah dilakukan oleh pihak Dinas Pendidikan Kota Pontianak. Pemilihan tersebut didasarkan pada jumlah sebaran sekolah dasar yang ada di Kota Pontianak. Seperti terlihat dalam tabel, pada Kecamatan Pontianak Barat, Timur, dan Utara lebih sering dilakukan pengetesan UKBI 
Tuah Talino

Tahun XIV Volume 14 Nomor 2 Edisi 4 Desember 2020

ISSN 0216-079X E-ISSN 2685-3043

Balai Bahasa Kalimantan Barat

daripada wilayah lain. Ini dikarenakan jumlah sekolah dasar di wilayah tersebut lebih banyak daripada wilayah lainnya.

Dari sekian banyak sekolah dan guru SD di Kota Pontianak, tulisan ini mengambil sampe 150 sekolah dari enam kecamatan, yaitu kecamatan Pontianak Kota, Pontianak Barat, Pontianak Timur, Pontianak Utara, Pontianak Tenggara, maupun Pontianak Selatan. Kemudian,setiap sekolah dipilih 12 guru SD, baik laki-laki maupun perempuan. Dengan demikian, terpilihlah 600 orang guru. Sekolah-sekolah sampel tersebut dipilih secara acak oleh Dinas Pendidikan Kota berdasarkan kriteria yang telah ditetapkan olen instansi tersebut.

Data yang telah diperoleh tersebut selanjutnya dianalisis secara kuantitatif sederhana dan dipaparkan atau dideskripsikan secara deskriptif untuk mengetahui kemampuan berbahasa Indonesia para guru SD di Kota Pontianak. Penganalisisan tersebut dilakukan dengan tahapan sebagai berikut. Pertama mengumpulkan atau merekapitulasi hasil UKBI para guru SD tersebut. Kedua mengelompokkan peuji berdasarkan nilai skor yang diperoleh. Ketiga, berdasarkan tiap level yang diperoleh peuji, penulis menerafkan seksi manakah yang paling dikuasai para guru pada masing-masing level. Selanjutnya, penulis juga melihat intensitas kemunculan nilai per seksi yang paling dikuasai para guru pada masing-masing level tadi. Hal ini dilakukan untuk mengetahui bidang manakah yang mayoritas dikuasai dan kurang dikuasai oleh para guru tersebut.

Pada tahap penyajian data, tulisan ini menggunakan metode kualitatif dengan cara informal untuk memaparkan hasil data kuantitatif sederhana tadi. Data kuantitatif tersebut disajikan dalam bentuk tabel dan gambar.

\section{PEMBAHASAN}

\section{Peringkat Kemahiran Berbahasa Indonesia Guru SD di Kota Pontianak}

Balai Bahasa Kalimantan Barat telah melakukan pengujian kemahiran berbahasa Indonesia terhadap 600 orang guru SD yang tersebar di enam kecamatan (seperti terlihat pada tabel 1). Dari hasil pengujian tersebut diperoleh hasil bahwa para guru SD di Kota Pontianak berhasil mencapai lima predikat saja, yaitu Sangat Unggul, Unggul, Madya, Semenjana, dan Marjinal. Untuk predikat Istimewa sebagai predikat tertinggi dan Terbatas sebagai predikat terbawah, tidak ada satu orang pun yang mencapainya. Dengan kata lain, tidak ada satu pun guru SD di Kota Pontianak yang dapat mencapai predikat tertinggi. Sebaliknya, tidak ada satu pun guru SD di Kota Pontianak yang keterampilan berbahasanya berada pada level terakhir/terbawah.

Masing-masing peringkat yang dicapai tidak diperoleh dengan jumlah yang sama oleh para guru tersebut. Artinya, ada peringkat yang banyak dicapai oleh guru-guru tersebut dan ada pula yang sedikit. Berikut ini adalah paparan hasil capaian UKBI para guru SD. 
Tahun XIV Volume 14 Nomor 2 Edisi 4 Desember 2020

ISSN 0216-079X E-ISSN 2685-3043

Balai Bahasa Kalimantan Barat

Tabel 2

Hasil UKBI Guru

\begin{tabular}{|c|c|c|c|}
\hline NO & PERINGKAT/PREDIKAT & JUMLAH PEUJI & $\%$ \\
\hline 1. & Sangat Unggul & 50 orang guru & $8,3 \%$ \\
\hline 2. & Unggul & 133 orang guru & $22,2 \%$ \\
\hline 3. & Madya & 261 orang guru & $43,5 \%$ \\
\hline 4. & Semenjana & 131 orang guru & $21,8 \%$ \\
\hline 5. & Marjinal & 25 orang guru & $4,2 \%$ \\
\hline \multicolumn{2}{|r|}{ Jumlah } & 600 orang guru & $100 \%$ \\
\hline
\end{tabular}

Bentangan tabel tadi memperlihatkan bahwa mayoritas guru memperoleh peringkat Madya. Ini terlihat dari banyaknya guru yang mencapai nilai tersebut, yaitu sebanyak 261 orang. Jika dipersentasekan, ada sekitar 43,5\% dari 600 orang guru yang mengikuti tes UKBI dan memperoleh predikat Madya. Di bawah peringkat Madya, ada sekitar 133 orang guru yang memperoleh predikat Unggul. Predikat ini merupakan peringkat ke-2 yang tertinggi yang diperoleh para guru SD di Kota Pontianak. Hal ini terlihat dari hasil persentase sekitar 22,2\% dari 600 orang guru.

Selanjutnya adalah Semenjana. Peringkat ini diperoleh 131 orang guru. Jika dipersentasekan ada sekitar $21,8 \%$ guru yang memperoleh predikat ketiga dari bawah. Berikutnya adalah Sangat Unggul. Ada sekitar 50 atau 8,3\% orang guru yang memperoleh predikat Sangat Unggul ini. Terakhir Marjinal, yaitu peringkat kedua terbawah dari tujuh peringkat UKBI ini diperoleh 25 orang guru SD. Jika dipersentasekan, ada sekitar 4,2\% dari 600 orang guru yang memperoleh peringkat tersebut.

Dilihat dari hasil tersebut, mayoritas guru SD di Kota Pontianak kemampuan UKBInya berada pada Peringkat Madya. Artinya, kemahiran berbahasa para guru tersebut berada pada tataran memadai, tidak terlalu tinggi dan sebaliknya tidak terlalu rendah. Namun demikian, para peuji yang berada pada Predikat Madya ini masih dapat dikatakan bahwa kompetensi berbahasa Indonesianya baik.

Peringkat berikutnya yang banyak dicapai oleh para guru SD tersebut adalah Predikat Unggul. Para peuji yang berada pada predikat ini dapat dikatakan bahwa kemahiran berbahasanya berada pada tataran tinggi. Setelah Unggul, predikat yang banyak dicapai pada guru tersebut adalah Predikat Semenjana. Para peuji yang berada pada taraf ini dapat dikatakan bahwa kemahiran berbahasanya cukup memadai.

Seperti terlihat pada tabel, dua predikat lainnya yang dicapai oleh para guru SD di Kota Pontianak adalah Sangat Unggul dan Marjinal. Para guru SD di Kota Pontianak yang mencapai Predikat Sangat Unggul dapat dikatakan bahwa kemampuan berbahasanya berada pada tataran sangat tinggi. Sebaliknya, para guru yang berada pada peringkat Marjinal, kemahiran berbahasanya berada pada tataran tidak memadai. 
Tahun XIV Volume 14 Nomor 2 Edisi 4 Desember 2020

ISSN 0216-079X E-ISSN 2685-3043

Balai Bahasa Kalimantan Barat

\section{Nilai Tertinggi dari Komponen Kebahasaan pada Tiap Peringkat}

Setelah diperoleh peringkat atau predikat tertinggi dan terbanyak yang berhasil dicapai oleh guru-guru tersebut, penulis mengkaji skor tertinggi yang diperoleh para guru para tiap-tiap peringkat yang berhasil dicapai tadi. Berikut ini adalah hasil skor tersebut.

\section{Tabel 3}

Skor Tertinggi pada Setiap Peringkat

\begin{tabular}{|l|c|c|c|}
\hline NO & PREDIKAT & SKOR TERTINGGI & NAMA SEKSI \\
\hline 1. & Sangat Unggul & 776 & Seksi 2 Merespons Kaidah \\
\hline 2. & Unggul & 725 & Seksi 3 Memahami Bacaan \\
\hline 3. & Madya & 680 & Seksi 3 Memahami Bacaan \\
\hline 4. & Semenjana & 590 & Seksi 3 Memahami Bacaan \\
\hline 5. & Marjinal & 530 & Seksi 3 Memahami Bacaan \\
\hline
\end{tabular}

Berdasarkan tabel tersebut terlihat bahwa skor tertinggi pada predikat Sangat Unggul adalah komponen Merespons Kaidah, yaitu 776. Pada predikat selanjutnya, Unggul, komponen yang tertinggi yang diperoleh adalah seksi Memahami Bacaan. Pada predikat ini, skor tertinggi yang diperoleh adalah 725 .

Predikat ketiga yang diperoleh para guru adalah Madya. Pada peringkat ini skor tertinggi yang dicapai adalah 680. Komponen kebahasaan yang memperoleh skor tertinggi pada peringkat Madya ini adalah Memahami Bacaan. Peringkat berikutnya adalah Semenjana dan Marjinal. Skor untuk dua predikat terakhir ini adalah 590 dan 530. Komponen kebahasaan yang berskor tertinggi pada dua predikat terakhir tadi adalah memahami Bacaan.

Dari bentangan tabel 2 terlihat bahwa, para guru SD di Kota Pontianak memperoleh skor tertinggi pada komponen Memahami Bacaan. Skor tertinggi ini terlihat pada predikat Unggul, Madya, Semenjana, dan Marjinal. Berbanding terbalik dengan empat peringkat tadi, para guru yang berpredikat Sangat Unggul berskor tertinggi terhadap komponen Merespons kaidah. Itu artinya pemahaman guru-guru SD di Kota Pontianak terhadap komponen Memahami bacaan dan Merespons Kaidah lebih tinggi daripada komponen kebahasaan lainnya.

\section{Intensitas Komponen Kebahasaan yang Dicapai}

Untuk mlengkapi deskripsi tentang kompetensi berbahasa Indonesia guruguru SD di Kota Pontianak, penulis mengkaji intensitas komponen kebahasaan yang dicapai oleh para guru tersebut. Jika sebelumnya telah diketahui bahwa mayoritas para guru SD itu berada pada peringkat Madya dan pemahaman terhadap bacaan dan kaidah bahasa Indonesia adalah kompetensi yang memperoleh nilai tertinggi pada masing-masing peringkat, pada bagian ini akan dibahas komponen kebahasaan yang dikuasai dan kurang dikuasai para peuji secara individual. Berikut ini adalah tabel yang memperlihatkan intensitas bidang komponen kebahasaan para peuji. 
Tuah Talino

Tahun XIV Volume 14 Nomor 2 Edisi 4 Desember 2020

ISSN 0216-079X E-ISSN 2685-3043

Balai Bahasa Kalimantan Barat

Tabel 4

Intensitas Skor Bidang Kemahiran Berbahasa

\begin{tabular}{|c|c|c|c|c|c|c|c|}
\hline \multirow{3}{*}{ NO } & \multirow{3}{*}{ PREDIKAT } & \multicolumn{6}{|c|}{ KOMPONEN KEBAHASAAN } \\
\hline & & \multicolumn{2}{|c|}{$\begin{array}{c}\text { SEKSI I: } \\
\text { MENDENGARKAN } \\
\end{array}$} & \multicolumn{2}{|c|}{$\begin{array}{c}\text { SEKSI 2: } \\
\text { MERESPONS KAIDAH } \\
\end{array}$} & \multicolumn{2}{|c|}{$\begin{array}{c}\text { SEKSI 3: } \\
\text { MEMAHAMI BACAAN } \\
\end{array}$} \\
\hline & & $\begin{array}{c}\text { SKO } \\
\text { R }\end{array}$ & INTENSITAS & SKOR & INTENSITAS & SKOR & INTENSITAS \\
\hline \multirow[t]{9}{*}{1.} & \multirow{9}{*}{$\begin{array}{l}\text { Sangat } \\
\text { Unggul }\end{array}$} & 605 & 3 kali/peuji & 560 & 3 kali/peuji & 620 & $1 \mathrm{kali} /$ peuji \\
\hline & & 620 & 9 kali/peuji & 584 & $2 \mathrm{kali} /$ peuji & 650 & 6 kali/peuji \\
\hline & & 635 & $4 \mathrm{kali} /$ peuji & 608 & $8 \mathrm{kali} /$ peuji & 665 & $7 \mathrm{kali} /$ peuji \\
\hline & & 650 & $3 \mathrm{kali} /$ peuji & 632 & $\begin{array}{c}17 \\
\text { kali/peuji }\end{array}$ & 680 & $\begin{array}{c}18 \\
\text { kali/peuji }\end{array}$ \\
\hline & & 665 & $10 \mathrm{kali} /$ peuji & 656 & $9 \mathrm{kali} /$ peuji & 695 & 9 kali/peuji \\
\hline & & 680 & 10 kali/peuji & 680 & $8 \mathrm{kali} /$ peuji & 710 & 6 kali/peuji \\
\hline & & 695 & 7 kali/peuji & 704 & $2 \mathrm{kali} /$ peuji & 725 & 3 kali/peuji \\
\hline & & 710 & 2 kali/peuji & 776 & $1 \mathrm{kali} / \mathrm{peuji}$ & - & - \\
\hline & & 725 & $2 \mathrm{kali} /$ peuji & - & - & - & - \\
\hline \multirow[t]{13}{*}{2.} & \multirow[t]{13}{*}{ Unggul } & 485 & $1 \mathrm{kali} /$ peuji & 512 & 8 kali/peuji & 575 & 5 kali/peuji \\
\hline & & 515 & $3 \mathrm{kali} /$ peuji & 536 & $\begin{array}{c}17 \\
\text { kali/peuji }\end{array}$ & 590 & 4 kali/peuji \\
\hline & & 530 & 6 kali/peuji & 560 & $\begin{array}{c}26 \\
\text { kali/peuji }\end{array}$ & 605 & $\begin{array}{c}13 \\
\text { kali/peuji }\end{array}$ \\
\hline & & 545 & $10 \mathrm{kali} / \mathrm{peuji}$ & 584 & $\begin{array}{c}23 \\
\text { kali/peuji }\end{array}$ & 620 & $\begin{array}{c}18 \\
\text { kali/peuji }\end{array}$ \\
\hline & & 560 & 17 kali/peuji & 608 & $\begin{array}{c}32 \\
\text { kali/peuji } \\
\end{array}$ & 635 & $\begin{array}{c}21 \\
\text { kali/peuji }\end{array}$ \\
\hline & & 575 & $18 \mathrm{kali} / \mathrm{peuji}$ & 632 & $\begin{array}{c}14 \\
\text { kali/peuji }\end{array}$ & 650 & $\begin{array}{c}23 \\
\text { kali/peuji }\end{array}$ \\
\hline & & 590 & 15 kali/peuji & 656 & $\begin{array}{c}12 \\
\text { kali/peuji }\end{array}$ & 665 & $\begin{array}{c}15 \\
\text { kali/peuji }\end{array}$ \\
\hline & & 605 & $19 \mathrm{kali} / \mathrm{peuji}$ & 680 & $1 \mathrm{kali} /$ peuji & 680 & $\begin{array}{c}16 \\
\text { kali/peuji }\end{array}$ \\
\hline & & 620 & $19 \mathrm{kali} / \mathrm{peuji}$ & - & - & 695 & $\begin{array}{c}11 \\
\text { kali/peuji }\end{array}$ \\
\hline & & 635 & $10 \mathrm{kali} / \mathrm{peuji}$ & - & - & 710 & $5 \mathrm{kali} / \mathrm{peuji}$ \\
\hline & & 650 & 9 kali/peuji & - & - & 725 & 2 kali/peuji \\
\hline & & 665 & $5 \mathrm{kali} /$ peuji & - & - & - & - \\
\hline & & 695 & $1 \mathrm{kali} /$ peuji & - & - & - & - \\
\hline \multirow[t]{7}{*}{3.} & \multirow[t]{7}{*}{ Madya } & 380 & $1 \mathrm{kali} /$ peuji & 248 & $1 \mathrm{kali} /$ peuji & 455 & 2 kali/peuji \\
\hline & & 395 & $3 \mathrm{kali} /$ peuji & 272 & $1 \mathrm{kali} /$ peuji & 470 & 5 kali/peuji \\
\hline & & 410 & $3 \mathrm{kali} /$ peuji & 296 & $1 \mathrm{kali} /$ peuji & 485 & 5 kali/peuji \\
\hline & & 425 & 6 kali/peuji & 320 & $2 \mathrm{kali} /$ peuji & 500 & 7 kali/peuji \\
\hline & & 440 & 8 kali/peuji & 368 & $4 \mathrm{kali} /$ peuji & 515 & $9 \mathrm{kali} / \mathrm{peuji}$ \\
\hline & & 455 & 19 kali/peuji & 392 & $5 \mathrm{kali} /$ peuji & 530 & $\begin{array}{c}21 \\
\text { kali/peuji }\end{array}$ \\
\hline & & 470 & 19 kali/peuji & 416 & 18 & 545 & 18 \\
\hline
\end{tabular}


Tuah Talino

Tahun XIV Volume 14 Nomor 2 Edisi 4 Desember 2020

ISSN 0216-079X E-ISSN 2685-3043

Balai Bahasa Kalimantan Barat

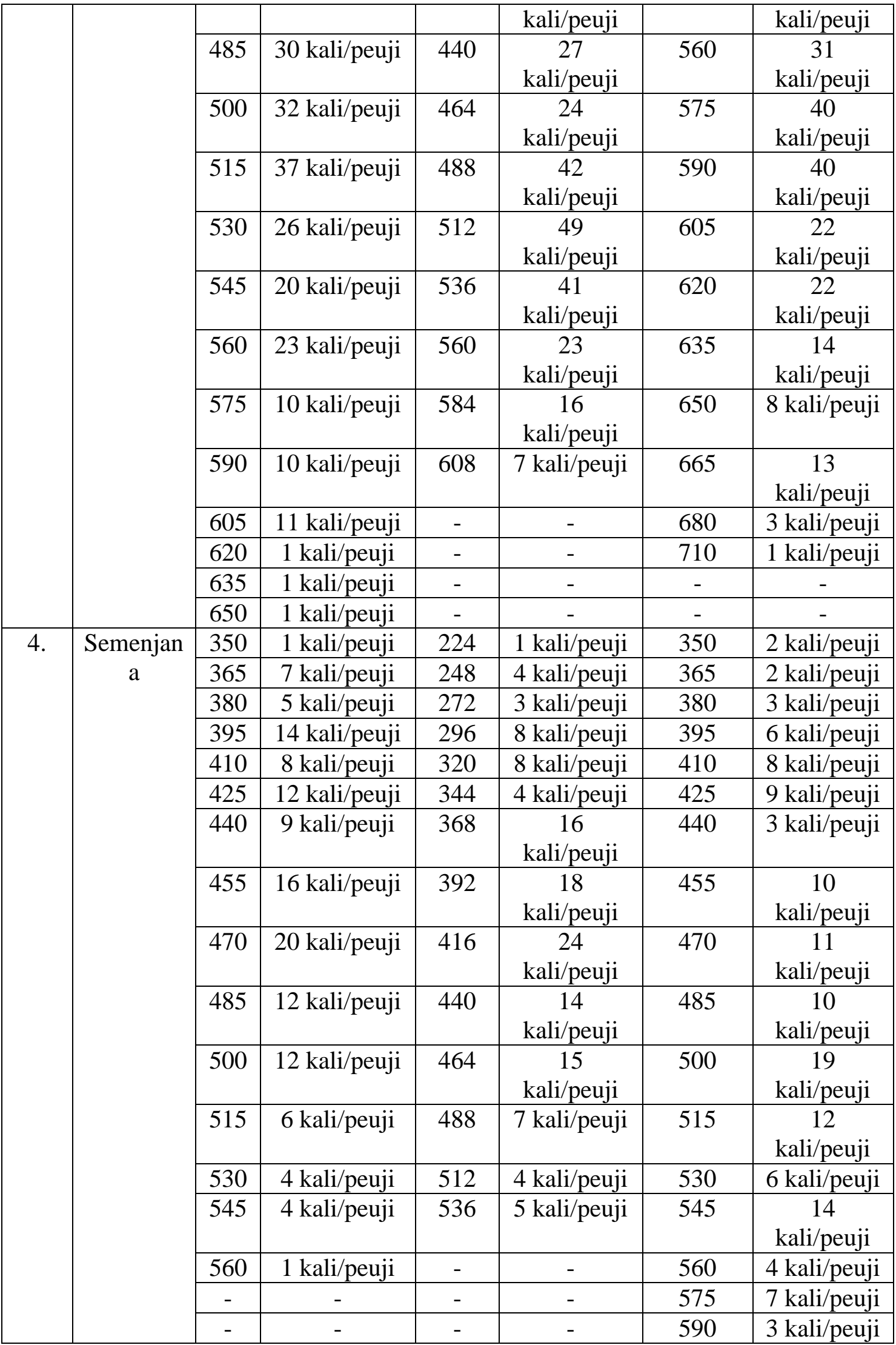


Tuah Talino

Tahun XIV Volume 14 Nomor 2 Edisi 4 Desember 2020

ISSN 0216-079X E-ISSN 2685-3043

Balai Bahasa Kalimantan Barat

\begin{tabular}{|c|c|c|c|c|c|c|c|}
\hline & & - & - & - & - & 635 & $1 \mathrm{kali} / \mathrm{peuji}$ \\
\hline & & - & - & - & - & 665 & $1 \mathrm{kali} /$ peuji \\
\hline \multirow[t]{13}{*}{5.} & \multirow[t]{13}{*}{ Marjinal } & 335 & 3 kali/peuji & 200 & $2 \mathrm{kali} /$ peuji & 290 & $1 \mathrm{kali} /$ peuji \\
\hline & & 365 & $2 \mathrm{kali} /$ peuji & 224 & $2 \mathrm{kali} /$ peuji & 320 & $1 \mathrm{kali} / \mathrm{peuji}$ \\
\hline & & 380 & $1 \mathrm{kali} /$ peuji & 248 & $1 \mathrm{kali} /$ peuji & 380 & $3 \mathrm{kali} / \mathrm{peuji}$ \\
\hline & & 395 & $5 \mathrm{kali} /$ peuji & 272 & $2 \mathrm{kali} /$ peuji & 395 & $1 \mathrm{kali} /$ peuji \\
\hline & & 410 & $5 \mathrm{kali} /$ peuji & 296 & $4 \mathrm{kali} /$ peuji & 410 & $2 \mathrm{kali} /$ peuji \\
\hline & & 425 & $3 \mathrm{kali} /$ peuji & 320 & $3 \mathrm{kali} / \mathrm{peuji}$ & 425 & $2 \mathrm{kali} / \mathrm{peuji}$ \\
\hline & & 440 & $3 \mathrm{kali} /$ peuji & 344 & $4 \mathrm{kali} /$ peuji & 440 & $3 \mathrm{kali} / \mathrm{peuji}$ \\
\hline & & 445 & $1 \mathrm{kali} /$ peuji & 368 & $3 \mathrm{kali} /$ peuji & 455 & $3 \mathrm{kali} /$ peuji \\
\hline & & 470 & 2 kali/peuji & 392 & 4 kali/peuji & 470 & 2 kali/peuji \\
\hline & & - & - & - & - & 485 & $1 \mathrm{kali} /$ peuji \\
\hline & & - & - & - & - & 500 & $3 \mathrm{kali} / \mathrm{peuji}$ \\
\hline & & - & - & - & - & 515 & $3 \mathrm{kali} /$ peuji \\
\hline & & - & - & - & - & 530 & $1 \mathrm{kali} /$ peuji \\
\hline
\end{tabular}

Dari tabel tersebut terlihat bahwa pada predikat Sangat Unggul, skor dalam seksi 1 yang sering muncul adalah 665, yaitu sebanyak 10 kali. Tidak hanya itu, terdapat pula skor 680 yang dicapai oleh 10 peuji lainnya. Sementara itu, skor yang paling sedikit diperoleh peuji adalah 710 dan 725. Kedua skor ini muncul sebanyak 2 kali untuk setiap skornya. Selanjutnya, pada seksi 2, skor terbanyak muncul adalah 632, yaitu sebanyak 17 kali. Sebaliknya, skor 776 sebagai skor tertinggi pada predikat Sangat Unggul ini malah muncl hanya sekali. Artinya, hanya ada satu peuji yang mencapai nilai tersebut. Kemudian, untuk seksi 3, skor terbanyak adalah 680 dan muncul sebanyak 18 kali, sedangkan skor 260 hanya muncul sekali.

Berikutnya adalah predikat Unggul. Untuk predikat ini pada seksi mendengarkan, skor 605 dan 620 muncul dengan jumlah yang sama, yaitu 19 kali. Artinya, ada 19 peuji yang memperoleh skor 605 dan ada 19 peuji lainnya yang memperoleh skor 620. Sebaliknya, peuji yang memperoleh skor 485 hanya ada 1 orang dan skor 695 juga hanya 1 orang. Seksi berikutnya adalah seksi merespons kaidah. Pada bagian ini terdapat sebanyak 32 peuji yang memperoleh skor 608 . Sebaliknya, terdapat hanya 1 peuji yang memperoleh skor 680. Kemudian, pada seksi kemampuan Memahami Bacaan terdapat 23 peuji yang memperoleh skor 650 dan hanya 1 peuji yang memperoleh skor 725 .

Predikat selanjutnya adalah Madya. Predikat ini adalah tingkat kemahiran yang mayoritas dikuasai oleh para peuji, yaitu sebanyak 43,5\%. Berdasarkan tabel 4, terlihat bahwa skor 515 diperoleh oleh 37 peuji pada seksi mendengarkan, sedangkan skor 380 diperoleh oleh 1 peuji. Pemerolehan yang sama juga terlihat pada skor 620, 635, dan 650, yaitu sebanyak 1 peuji untuk tiap-tiap skornya. Kemudian, untuk seksi merespons kaidah, skor 512 dicapai oleh 49 peuji. Sebaliknya, skor 248 dicapai oleh 1 peuji. Pencapaian ini juga terjadi pada skor 272 dan 296 yang juga hanya dicapai oleh 1 peuji untuk setiap skornya. Seksi ketiga, Memahami Bacaan, terlihat bahwa ada 40 peuji yang mencapai skor 575 dan 590, sedangkan skor 710 hanya dicapai oleh 1 peuji. 
Tuah Talino

Tahun XIV Volume 14 Nomor 2 Edisi 4 Desember 2020

ISSN 0216-079X E-ISSN 2685-3043

Balai Bahasa Kalimantan Barat

Predikat berikutnya yang dicapai para guru SD di Kota Pontianak adalah Semenjana. Pada predikat ini, intensitas skor seksi 1 yang dicapai oleh peuji adalah 470 sebanyak 20 kali dan 350 sebanyak 1 kali serta 560 sebanyak 1 kali. Di samping itu, intensitas skor untuk seksi 2 yang dicapai oleh para guru tersebut adalah 416 sebanyak 24 kali dan 224 sebanyak 1 kali.

Tingkat kemahiran terakhir yang dicapai oleh para guru SD di Kota Pontianak adalah Marjinal. Pada tingkat kemahiran berbahasa ini, skor 395 dicapai oleh 5 peuji untuk seksi 1. Begitu pula dengan skor 410 yang juga dicapai oleh 5 peuji lainnya. Sebaliknya, skor 380 dicapai oleh 1 peuji. Begitu pula dengan skor 445 yang dicapai oleh 1 peuji lainnya.

\section{Interpretasi Kemahiran Berbahasa Indonesia Secara Reseptif Para Guru SD}

Berdasarkan paparan pembahasan data, diketahui bahwa taraf keterampilan aktif reseptif dan pemahaman kaidah bahasa Indonesia para guru SD se-Kota Pontianak berada pada taraf sangat tinggi (Sangat Unggul), tinggi (Unggul), memadai (Madya), dan cukup memadai (Semenjana), dan tidak memadai (Marjinal).

Para guru yang berada pada level sangat tinggi tingkat dalam berkomunikasi secara reseptif tidak mengalami kendala dalam berkomunikasi untuk keperluan sintas, sosial, dan keprofesian. Kendala baru dirasakan ketika mereka berhadapan dengan komunikasi yang berkaitan dengan permasalahan akademik yang kompleks.

Selanjutnya, para guru yang tingkat kemahiran reseptifnya berada pada taraf sangat memadai tidak memiliki kendala dalam memahami komunikasi yang berkaitan dengan masalah personal/kesintasan dan sosial. Selain itu, proses komunikasi yang berkaitan dengan permasalahan keprofesian juga tidak menjadi kendala bagi para peuji yang kemahirannya berada pada taraf tinggi ini. Kondisi tidak terkendala tersebut dapat terjadi pula pada bidang keprofesian, baik sederhana maupun rumit. Pada taraf ini pula para peuji masih mengalami kendala berkomunikasi untuk keperluan akademik.

Sementara itu, para guru SD yang tingkat kemahiran berbahasanya berada pada level memadai mampu memahami komunikasi untuk keperluan sintas dan sosial atau kemasyarakatan dengan baik. Akan tetapi, untuk bentuk komunikasi yang berkaitan dengan keperluan keprofesionalan yang kompleks dan keilmiahan, para peuji ini mengalami kendala.

Para guru SD se-Kota Pontianak yang tingkat kemahiran berbahasa reseptifnya berada pada taraf cukup memadai dapat memahami komunikasi yang berkaitan dengan permasalahan kesintasan secara baik. Proses komunikasi yang berkaitan dengan keprofesian dan kemasyarakatan yang tidak kompleks juga tidak menjadi kendala bagi para peuji yang berada pada taraf ini. Itu artinya, para peuji yang berada pada level ini akan menghadapi kendala untuk memahami komunikasi yang berkaitan dengan masalah keprofesian dan kemasyarakatn yang kompleks. Begitu pula dengan tema-tema komunikasi untuk kelimiahan, yang bersangkutan sangat terkendala.

Dalam berkomunikasi untuk keperluan kesintasan dan kemasyarakatan yang sederhana, para peuji yang berada pada level tidak memadai kemahiran 
Tuah Talino

Tahun XIV Volume 14 Nomor 2 Edisi 4 Desember 2020

ISSN 0216-079X E-ISSN 2685-3043

Balai Bahasa Kalimantan Barat

berbahasanya ini tidak mengalami kendala. Akan tetapi, untuk keperluan kemasyarakatan yang kompleks, yang bersangkutan masih mengalami kendala. Hal ini berarti mereka belum siap berkomunikasi untk keperluan keprofesian, apalagi untuk keperluan keilmiahan.

\section{PENUTUP}

Sebagai tenaga pengajar yang dituntut memiliki kompetensi di bidang bahaa Indonesia, kemampuan berbahasa Indonesia guru SD di Kota Pontianak dapat dikatakan sangat memadai, memadai, dan cukup memadai. Ini dikarenakan mayoritas guru tersebut berada di peringkat Unggul, Madya, dan Semenjana. Guru yang memperoleh tiga peringkat tersebut berjumlah lebih dari seratus orang.

Di samping itu, jika dilihat dari tingginya nilai skor yang diperoleh dari tiga komponen kebahasan yang diujikan, komponen Memahami Bacaan dan Merespons Kaidah bahasa Indonesia adalah dua komponen yang memperlihatkan hal tersebut. Untuk predikat Unggul, Madya, Semenjana, dan Marjinal, nilai tertinggi berada pada komponen Memahami Bacaan. Kemudian, untuk predikat Sangat Unggul, nilai tertinggi berada pada komponen Merespons Kaidah.

Akan tetapi, jika dilihat dari kemampuan personal seluruh peserta uji yang didasarkan pada intensitas skor yang dicapai, dapat dikatakan bahwa guru-guru SD yang berada pada level Unggul, Madya, Semenjana, dan Marjinal lebih menguasai komponen Merespons Kaidah. Sebaliknya, komponen Memahami Bacaan lebih dikuasai oleh para peuji yang berada pada level Sangat Unggul.

Fenomena ini memperlihatkan bahwa adanya ketidaksejajaran antara pemerolehan nilai tertinggi dengan tingkat penguasaan kebahasaan secara personal seluruh peserta uji. Artinya, skor tertinggi pada komponen kebahasaan yang diujikan berlum mencerminkan kemampuan personal seluruh peserta uji.

Sementara itu, komponen kebahasaan yang kurang dikuasai oleh peserta uji adalah komponen Mendengarkan untuk level Unggul dan Madya. Kemudian, komponen mendengarkan juga terlihat kurang dikuasai oleh peserta uji yang berada pada level Semenjana (selain komponen Memahami Bacaan). Komponen Memahami Bacaan juga terlihat kurang dikuasai untuk para peserta uji yang berada pada level Marjinal dan Sangat Unggul—komponen Merespon Kaidah juga kurang dikuasai oleh peuji yang berada pada level Sangat Unggul. Penentuan ini didasarkan pada intensitas skor yang muncul hanya 1 kali yang artinya bahwa hanya 1 peuji yang mencapainya.

\section{DAFTAR PUSTAKA}

https://ukbi.kemdikbud.go.id.

Budhiono, R. Hery. (2017). Kompetensi Berbahasa Indonesia Guru Sekolah Dasar di Kalimantan Tengah. https://doi.org/10.26499/salingka.v14i01.51

Ibrahim, Ali Gufron, dkk. (2016). Pedoman Uji Kemahiran Berbahasa Indonesia. Jakarta: Badan Pengembangan dan Pembinaan Bahasa. 
Tuah Talino

Tahun XIV Volume 14 Nomor 2 Edisi 4 Desember 2020

ISSN 0216-079X E-ISSN 2685-3043

Balai Bahasa Kalimantan Barat

Maryanto. (2010). Tes Uji Kemahiran Berbahasa Indonesia (UKBI) sebagai Arena Riset Linguistik. htpps://doi.org/10.26499/wdprw.v38i.11

Pramesti, Utami Dewi. (2015). Peningkatan Penguasaan Kosakata Bahasa dalam keterampilan Membaca Melalui Teka-Teki Silang. Puitika 11(1) 82-93.

Syahrir, Elvina. (2014). Kemampuan Guru Bahasa Indonesia dalam Menyelesaikan Soal UKBI di Pekanbaru. https://doi 10.26499/madah.v5i2.502

Mulyati, Yeti dan Cahyani, Isah. (2015). Materi Pokok Keterampilan Berbahasa Indonesia SD. Cetakan I Edisi 2. Tangerang Selatan: Universitas Terbuka.

Mulyati, Yeti. (2015). Hakikat Keterampilan Berbahasa. Modul 1. Repository.ut.ac.id. 1.1-1.34.

Wahyuni, Sri. (2013). Hubungan Antara Kepercayaan Diri dengan Kecemasan Berbicara di Depan Umum pada Mahasiswa Psikologi. http://ejournals.unmul.ac.id. Psikoborneo 1(4) 220-227.

Zalmansyah, Achril. (2013). Uji Kemahiran Berbahasa Indonesia (UKBI) bagi Guru dan Siswa Sekolah Menengah Pertama Se-Lampung Utara. Sirok Bastra 2(1) 79-87.

(2016). Tes Kemahiran Berbahasa Indonesia Bagi Guru Bidang Studi Bahasa Indonesia Tingkat SLTA Se-Kabupaten Pringsewu. Totobuang. 4(2) $219-229$. 